\title{
Inspired From the Taiwanese Kao-Hsiung Model, Executed with Mauritian Flair: From Basket Case to Middle Income Country
}

\author{
Satyadev Rosunee ${ }^{1, *}$, Jacquelene Robeck ${ }^{2}$, Jessica Pattison ${ }^{3}$ \\ ${ }^{1}$ Faculty of Engineering, University of Mauritius, Reduit, Mauritius \\ ${ }^{2}$ Fashion Design and Merchandising, School of Architecture and Design, University of Louisiana, Lafayette, 70504, USA \\ ${ }^{3}$ Textiles, Apparel \& Merchandising Department, Louisiana State University, Baton Rouge, 70803, USA \\ *Corresponding Author: s.rosunee@uom.ac.mu
}

Copyright (C) 2013 Horizon Research Publishing All rights reserved.

\begin{abstract}
The Mauritius Export Processing Zone (MEPZ) is originally modeled on the Kao-Hsiung EPZ, Taiwan. The literature credits Sir Edouard Lim Fat, a visionary Mauritian of Chinese descent, as the pioneer of the MEPZ. During a presentation at the International Sugar Congress (Mauritius, November 1969), he made a strong plea for government to emulate the Taiwanese Model to tackle socio-economic problems. One significant difference from other countries' "enclave-type" EPZs was that the entire island of Mauritius was 'declared' as EPZ. The MEPZ was underpinned by a wide array of tax incentives \& imaginative policy decisions making it one of the best performing economies in Africa-from USD 200 to over USD 10, 000 GDP per capita (middle income country). This paper will also describe the sustainable backward \& forward linkages that the EPZ has enabled, unleashing an entrepreneurship momentum that continues to grow.
\end{abstract}

Keywords Mauritius, Export Processing Zone, Small and Medium Enterprises, Business Linkages

\section{Introduction}

Mauritius is a small sub-tropical island of $2,040 \mathrm{~km}^{2}$ situated in the Indian Ocean, off the east coast of Madagascar. Just after independence from the British in 1968, Mauritius was a monocrop economy, totally (97\%) dependent on sugar exports. In addition the country had a severe unemployment problem. In 1961, J.E. Meade, Economics Professor from Cambridge University and future Nobel recipient, predicted a dismal future, famously quoting 'Mauritius' intractable economic problems'. To avoid social \& political unrest as well as economic bankruptcy, one of Meade's recommendations was the setting up of import-substitution industries (ISI) such as soap, tea, seafood, and clothing, but its success was minimal owing to the exiguity of the domestic market, lack of investment \& poor technological skills (Mohit, 2011; Yeung Lam Ko, 1998). By the end of the 1960 's, owing to the worsening employment situation, it was evident that the ISI strategy had failed \& existing enterprises were in a precarious financial situation.

Sir Edouard Lim Fat, utterly convinced about the viability of Kao-Hsiung EPZ model for Mauritius, made his case during a presentation at International Sugar Congress. He convinced a government delegation to visit Taiwan so that policy makers could see for themselves. Why Kao-Hsiung? Because both Mauritius and Taiwan are small islands with lots of similarities: no raw materials, a sizeable agricultural sector, relatively small domestic market, enterprising nature of its population. Taiwan had already adopted an export-oriented strategy (EOI) since the mid 1960's and it had been a resounding success.

Government acted quickly to capitalize on the competitive advantages of cheap \& plentiful labor and preferential trade agreements creating an advantageous situation for exports (Wong, 2011). The rise of the EPZ was swift, transforming profoundly the socio-economic fabric of the country, even creating an economic boom between 1983 \& 1988. As of May 2012 there are now 354 firms in Mauritius' EPZ, now referred to as EOE (Export Oriented Enterprises). Forty eight percent (170) of EOE firms are textile and clothing firms and $61 \%$ of EOE exports come from those firms (www.gov.mu).

Mauritius's combination of social \&political stability, democratic institutional framework, rule of law, low level of corruption, good infrastructure and favorable regulatory environment has laid the foundation for sustained economic growth. Mauritius is fully integrated with the global economy and promotes the free flow of capital, labor, goods and services. According to the annual Global Competitiveness Report (2013/14), Mauritius is the most competitive economy in Africa and ranks $45^{\text {th }}$ globally 
(World Economic Forum).Between 1977 and 2009, annualreal GDP growthaveraged 5.1\%, comparedto 3.2\% for Sub-SaharanAfrica (Zafar, 2011).

The University of Mauritius (UoM) was founded in 1965 supporting schools of agriculture, administration and industrial technology. Courses offered were in agriculture, technology, engineering and public administration subjects. Many students were sponsored by local industries leading to trained manpower. Sir (Professor) E Lim Fat is a former Head of the School of Industrial Technology, (now Faculty of Engineering). The UoM's Engineering Tower was re-named after him in recognition to his tremendous achievements in industry and academia.

\subsection{Major Policy Decisions \& Enabling Conditions}

1) The EPZ Act was passed in Parliament in December 1970; the whole island was qualified as EPZ;

2) EPZ businesses would:

a) have a tax holiday for the first 10 years, and would then pay $15 \%$ on dividends; b) have no applicable custom duties, enjoying duty free imports of raw materials and equipment; c) not subjected to customs controls; d) pay rent only for buildings built by the Mauritius government and developed by the Development Bank of Mauritius.

Positive results came swiftly. Five factories were set up in the MEPZ within the first few months, with over 500 employees. An additional incentive to join the MEPZ was that $10 \%$ dividends would be paid to shareholders. For every direct job created in the MEPZ, it was estimated that three indirect jobs were created elsewhere in the economy.

\section{Methodology}

A decade-wise literature review of the Mauritius EPZ was carried out, starting from the influence of the Kao-Hsiungmodel up to 2010. The ups and downs of the MEPZ have been faithfully charted out. The tremendously positive spill-over effects of the MEPZ over a wide spectrum of the domestic economy was investigated. 15 domestic Small \& Medium Enterprises (SMEs), self-employed/family firms, were interviewed to understand the effect of backward and forward business \& service linkages that have been established following 40 years of the EPZ. Mauritius was sub-divided into four quadrants and the following research questions were formulated:

1. Have manufacturing clusters emerged and in which sub-sector?

2. Types of backward linkages between SMEs \& large manufacturing enterprises;

3. Types of forward linkages between manufacturing SMEs \& other domestic sub-sectors such as tourism \& services.

\section{Results \& Discussions}

\subsection{Hong Kong as a Catalyst}

Textile \& apparel production has traditionally been the precursor of industrialization as the barrier to entry is very low. The original and majority of the textile/apparel stakeholders that implanted themselves early in the Mauritius EPZ were from Hong Kong (Berger, 2006). The MEPZ was an attractive location country for a number of reasons: 1) Arson in Hong Kong factories was prevalent in the 1960s; 2) Military clashes between China and Taiwan were feared; 3) Hong Kong families and firms had been forced out of Shanghai, leaving all possessions behind, after regime change in 1949; 4) Hong Kong had an established garment industry complete with equipment, technicians, and marketing strategies (Lim Fat, 2010).

The impending reversion of Hong Kong to China in 1997 created a feeling of insecurity. They didnot want to again experience financial losses from a government change as they did in 1949. They wanted to protect their investments and hold on to their financial earnings (Lim Fat, 2010). Thus, a combination of perfect timing with textile producers looking for new production bases \& markets \& Mauritius leaving no stone unturned to welcome investment. Many Hong Kong textile industry people came to Mauritius and brought apparel and textile machinery with them. Mauritius had plentiful labour and women preferred the factory work over working in the sugar plantations (Lim Fat, 2010).

In 1973 five (23\%) of the twenty two companies under the MEPZ umbrella were textile \& apparel companies. This early period of growth was in alignment with a period of political and social stability, availability of capital, previous sugar capital transferred to EPZ ventures, enthusiasm and faith locally and abroad (Lim Fat, 2010). The very active T \& A companies were knitwear companies formed from the French-Hong Kong-Mauritius liaison formed in Paris at industry fairs (Mohit, 2011; Tang 2011). 1973 also marked the year of the inception of the Multi Fibre Arrangement.

The first half of the 1970 decade was one of fast development for Mauritius export companies. The latter 1970's forced firms to acknowledge world finances, the oil crisis, capacity building, services, the need for public transportation connecting rural to urban, and political and economic uncertainty (Mohit, 2011). No growth was realized in the apparel/textile industry, among others. Mauritius received help from the International Monetary Fund and devalued the Mauritian currency (rupee) first by $30 \%$ and a second time by 20\%. In 1975 the Mauritius Export Development Authority, under the Ministry of Industry, with representatives in England, France and India helped to export Mauritian products (Lim Fat, 2010; Mohit 2011, Tang, 2011). Mauritius benefitted by the Lomé convention (signed in 1975 in Lomé, Togo) that provided added advantages to ACP (African, Caribbean, Pacific) countries, giving them preferential access to European markets - no duty was payable when ACP goods were exported to Europe. This duty-free preferential agreement impacted the attraction of foreign investors to Mauritius (Peerally \& Cantwell, 
2011). In 1976 the Mauritius Export Zone Association (MEPZA, changed in 2006 to MEXA) was formed and led by Mr. Lim Fat. MEXA would be the facilitator linking Mauritius EPZ enterprises with government to economically advance the country in the global market.

\subsection{0-1990: A Decade of Rapid Expansion}

In 1980 there were 98 enterprises in the MEPZ, expanding to 568 by the end of the decade. Many factors and situations contributed to this high growth of more than $450 \%$. When Hong Kong firms realized that they could retain their assets in China, many left Mauritius, leaving behind their equipment and the trained Mauritians. Local Mauritian investors took advantage of this situation and many from the sugar industry provided capital for the continuation of, or the formation of new textile and clothing firms. A civil war in Sri Lanka, where textile/apparel production had been increasing, shifted more production to Mauritius (Lim Fat, 2010). In 1990 the MEPZ had the greatest number of enterprises in its history (568) (Yin et al., 1992). The government reduced the $70 \%$ tax structure to $35 \%$ which promoted the development of more businesses by Mauritians. Forty five percent of the MEPZ equity capital was from Hong Kong, 44\% from Mauritius, 6\% from France, with the remaining 5\% from Germany, India, U.S., Singapore and Switzerland. The government executive committee boosted the development of the MEPZ through quick decisions, creating an advantageous situation for exports (Wong, 2011).

\subsection{0-2000: A Decade of Change}

In 1994 the Common Market for Eastern and Southern Africa (COMESA) which included Mauritius was signed as one of five Economic Partnership Agreements (EPAs) providing for special trade arrangements between COMESA countries and the European Union (EU). In 1995 Lomé IV afforded Mauritius preferential access to EU, aiding exports.

As China began opening up, many of the Hong Kong investors relocated their businesses to Viet Nam and China owing to lower production and labor costs. To counteract this trend, more local investors brought their capital from the sugar boom to the textile/apparel arena. Mauritians had gained skills \& experience from their Hong Kong guidance and the $\mathrm{T} \& \mathrm{~A}$ factories survived because of their automation and production of higher quality garments. Almost unique in the world, Mauritius reached full employment and the EPZ faced labor shortages. The Mauritius textiles and clothing industry experienced an employment peak in 1999 and outsourced to nearby Madagascar, where labour was cheaper. The flourishing tourism industry was a significant pull factor for factory workers who preferred the work of cleaning and waiting in a relaxed and enjoyable environment and garnering generous tips. Laborers in the apparel/textile area were brought in from Madagascar, Bangladesh, India and China. The decade ended with 500 EPZ firms; $58 \%$ were T \& A firms. There was speculation that Mauritius' exports were too heavy with T \& A industries (Wong, 2011).

\subsection{0 a Decade of Challenges}

The first years of the new millennium brought many challenges to the MEPZ. Quota privileges and duty free entry of Mauritian goods were phased out with the end of the Lomé agreement, but was replaced with the COTONOU Agreement (signed in Cotonou, Benin in 2000); this agreement prolonged the trade benefits package between ACP countries and the EU.

The African Growth and Opportunity Act (AGOA) signed in 2000 offered tangible incentives for African countries to continue their efforts to open up their economies and build free markets. It allowed duty free garment exports to the United States if made from local African or United States yarns or origination from U.S. or Africa. However, Mauritius was excluded from this agreement until 2006. AGOA promotes organic products, but a lot of water consumption is needed for organic products and Mauritius is promoting their ability to be eco-friendly in the world marketplace (Wong, 2011). The Southern African Development Community (SADC) signed in 2000 stated that those member countries (including Mauritius) would operate as a free trade area.

In 2003 Mauritius' apparel production began to delocalize to Madagascar to take advantage of cheap labor and to benefit from AGOA. Two years later, Mauritius immediately felt the impact with the dissolution of the MFA in 2005. Mauritius" "cut-make-trim" contracts went to China, India and Vietnam. Mauritius' exports to the U.S. decreased by $49 \%$ from 2004 to 2007 . T \& A manufacturers became involved in alternative strategies such as eco friendliness, low carbon footprint of products, and improved equipment and system technologies (Tang, 2011).Factory departments were restructured and productivity closely monitored. In 2005 the industry was employing 72,000 people for an export value of about 0.8 billion dollars. In 2012, for an export value of nearly 1.0 billion U.S. dollars employment stood at 40,000, indicating that restructuring and productivity improvement programs had yielded positive results.

The world recession of 2008 impacted Mauritius and the MEPZ was boosted with a one billion Mauritian rupees grant and successive reduction of interest rates prompting stabilization. The decade ended with 400 firms in the MEPZ; $47 \%$ were $\mathrm{T} \&$ A firms (Lim Fat, 2010).

\subsection{Sustaining the EPZ}

In May 2012 there were 354 firms in the MEPZ, now referred to as EOE (Export Oriented Enterprises). The EOE is comprised of all enterprises operating with an EPZ certificate. Apart from textile and clothing, EOEs now operate in diverse sectors such as seafood, light engineering, toys, jewelry, leather, eyewear, prosthetics, etc. Table 1 illustrates the contribution of EOEs tothe Mauritian economy.

The $\mathrm{T} \& \mathrm{~A}$ industry continues to contribute to Mauritian 
economy. T \& A accounts for $5 \%$ of the GDP, $8 \%$ of total employment and accounts for nearly $50 \%$ of total domestic exports. The major garments produced are t-shirts, pullovers, men's shirts and trousers which account for $90 \%$ of the total textile and clothing exports. The four major countries for exports are the United Kingdom (32\%), U.S. (17\%), South Africa (16\%) and France (16\%) (www.gov.mu).

Table 1. Contribution of EOEs in exports

\begin{tabular}{|c|c|c|c|c|c|c|}
\hline \multicolumn{7}{|c|}{ Export Oriented Enterprises } \\
\hline $\begin{array}{c}\text { Value added } \\
\text { at current } \\
\text { basic prices }\end{array}$ & $\begin{array}{c}\text { MUR } \\
(\mathrm{Bn})\end{array}$ & 17.8 & 17.8 & 17.4 & 17.3 & 19.1 \\
\hline $\begin{array}{c}\text { Value } \\
\text { added/GDP }\end{array}$ & $\%$ & 8.3 & 7.3 & 6.9 & 6.5 & 6.6 \\
\hline $\begin{array}{c}\text { No. of } \\
\text { enterprises }\end{array}$ & 404 & 412 & 413 & 372 & 360 \\
\hline Employment & MUR & 4.5 & 2.2 & 1.1 & 0.9 & 1.0 \\
\hline $\begin{array}{c}\text { Investment } \\
(\mathrm{Bn})\end{array}$ & $\begin{array}{c}\mathrm{MUR} \\
(\mathrm{Bn})\end{array}$ & 37.8 & 35.1 & 36 & 40.1 & 41.6 \\
\hline Exports & $\%$ & 54.3 & 51.6 & 58.3 & 59.1 & 60.1 \\
\hline $\begin{array}{c}\text { Exports/total } \\
\text { exports }\end{array}$ & $\%$ & 62,276 & 58,566 & 55,828 & 55,740 \\
\hline Imports & $\begin{array}{c}\text { MUR } \\
(\mathrm{Bn})\end{array}$ & 21 & 20.2 & 17.3 & 22.7 & 24.2 \\
\hline $\begin{array}{c}\text { Imports of } \\
\text { raw } \\
\text { materials/ } \\
\text { total imports }\end{array}$ & $\%$ & 86.8 & 94.3 & 84.9 & 86.5 & 97.7 \\
\hline
\end{tabular}

MUR= Mauritian Rupee (1.0 \$ US 30 MUR)

\subsection{Spill Overs \& Enterprise Linkages}

The impact of the EPZ on Mauritius' socio-economic fabric has been tremendous. Mauritius now has one of the most open economies in the world. In the 2010 Index of Economic Freedom, Mauritius ranked $13^{\text {th }}$ in a list of 183 countries while Hong Kong has consistently been ranked No.1 for 15 consecutive years (gfmag, 2010).

EPZ-driven industrialization has embedded and empowered an enterprising culture, has increased economic opportunity, attracted foreign direct investment, broadened access to a wide range of skills, finance, and technology. All SME directors interviewed reported that the MEPZ has enabled them to tap into broader production \& supply networks, innovative financing instruments, enhanced enterprise support services, trade promotion events. All commercial or development banks in Mauritius have a SME deskoffering innovative financial instruments/packages. SMEs working as sub-contractors for EPZ companies are more likely to secure financing from commercial banks.

Clusters: Unfortunately, despite the best efforts of a number of operators and supporting institutions, clusters started a few years ago could not be sustained. The main reason was significant disparity in financial capabilities of participating members. Although, over $65 \%$ of respondents understood the advantages of clusters, they could not make it work as the low cash flow of one member could severely impede the operations of the other members. Vastly dissimilar manufacturing strengths, product features and management methods also disrupted the smooth running of the cluster. One new element that cropped up during the interviews was that a cluster could not be set up as legal entity under current Mauritian laws. Some entrepreneurs also mentioned swings in orders affected their inventory \& cash flow. Stiff competition, lack of trust and extensive employee poaching may be responsible for the non-viability of clusters in Mauritius. Hence, there was no evidence of the formation of clusters in any of the four quadrants.

The backward linkages between larger enterprises \& SMEs have enabled SMEs to improve their financial performance as well as acquire skills \& technology. In textile \& apparel, most SMEs acted as sub-contractors for bigger enterprises, thus benefitting from exposure to new product designs, new technologies, and enhanced production \& quality control procedures. However, it was mentioned that the enduring European crisis was beginning to bite and bigger enterprises were self-sufficient in delivering slimmed-down orders from European customers.

Vertical integration in the textile sector has greatly benefitted SMEs in T\&A (Zhang \& Hathcote, 2008). It has given SMEs better access to a wider range differentiated fabrics and shorter production runs, enabling them to widen their range of product offerings. A weak point though is that weaving mills usually do not entertain fabric orders of less than two thousand metres, which are beyond the requirements of most Mauritian SMEs. Any fabric excess to requirement goes into inventory which over time represents a financial burden to the factory. The majority of SMEs are adopting good governance, eco-friendly production processes, fair trade and social compliance (Ittoo, 2011).

Some of the SME directors interviewed first learned the trade while employed in EPZ companies, (apparel making, watch assembly, stainless steel jewelry, soft toys, ceramics, etc.). They have now set up their own enterprises producing mid-range products that are more affordable to customers locally \& regionally. The African continent with a young and steadily growing middle class represents a potentially huge market. Mauritian entrepreneurs have been making inroads in Botswana, Ghana, Kenya, Ethiopia, Nigeria, etc. Government is focusing on a strategy to encourage EOEs to joins hands with SMEs in reaching out to African markets.Joint containerization of goods for shipping to regional markets was deemed to be more economical for SMEs. Hence Africa is expected to contribute significantly to export growth in the coming years.

The interviews revealed that locally sourced inputs have improved in diversity \& quality reflecting greater sophistication and purchasing power of domestic consumers. Some SMEs have developed newer strategies such as concentrating more on quality rather than quantity and brand development. Overall, the elimination of preferences are compelling Mauritius enterprises to modernize, upgrade to higher value added products and move into the upper segments of the market in order to remain competitive 
(Kilduff, 2006).

Some highly desirable backward linkages that were missing were: market intelligence, management training, joint R\&D projects and marketing initiatives but most importantly the spirit of innovation. The lack of innovation and rising labor cost was gradually undermining competitiveness resulting in low investment, poorer productivity and weaker rates of growth.

The forward linkages between manufacturing SMEs \& other domestic sub-sectors such as tourism \& services such as retail were prominent as both sectors continue to develop. The potential of the tourism sector was completely overlooked by Meade in his economic survey report in 1961, most probably because he believed that European tourists would find Mauritius a far-away destination. Mauritius now welcomes about 1.0 million tourists annually. SMEs operating in the craft sector have linked with hotel chains to develop a wide range of products \& services to meet criteria such as green, sustainable and fair-trade. Other SMEs are now specialized in providing elaborate services to the corporate sector, starting from staff uniform to events management. Forward linkages, in this era of intense competition \& globalization, tend to be more volatile as firms focus on 'value for money'. SMEs deemed themselves quite agile $\&$ responsive to market demands.

\section{Conclusions}

The future of the Mauritian EPZ along with SMEs is dependent on a number of factors: 1) Skilled labor and productivity, 2) Marketing strategies, 3) Trade agreements, and 4) Agility.

The cost of labor in Mauritius is higher than in many other third world countries. With relatively low unemployment (less than 5\%), Mauritius may again have to seek foreign labor or seek alternatives to labor costs. Mauritius' past strategies of low labor cost, productivity and low cost service are no longer applicable.

Positioning Mauritius' manufacturers as "green" and eco-friendly should impact world sourcing of their services (Wong, 2011).The backward \& forward linkages, if properly harnessed, could be a driver of innovation. Mauritius companies may have to sustain competitiveness through state of the art technology and vertical integration (Lim Fat, 2010; Ittoo, 2011).

Mauritius has earned the trust of world buyers. Companies are producing high-end quality products for diverse markets. They are able to compete on the basis of non- price factors and they have developed the ability to meet tight lead times (Domun, 2012).The EOEs wish to engage fully with the EU, African and US markets, via AGOA, COMESA, COTONOU, SADC and other Economic Partnership Agreements as these instruments provide preferential access to large global markets.

Mauritius' strengths lie in its small size, agility, responsiveness, quality products, customer-orientation, sustainable business approach and creativity.

\section{Acknowledgments}

Professor JacqueleneRobeck, Ph.D. was awarded a Fulbright Senior Scholar Award to teach and conduct research at the University of Mauritius in Reduit in 2011. She wishes to thank the kind people in her home department at the University of Mauritius and the Mauritius people for their support of her endeavors.

\section{REFERENCES}

[1] Berger S (2006) Made in Monde, Seuil: 140

[2] Domun R, Senior Industrial Analyst Mauritius Ministry of Industry, Commerce \& Consumer Protection. Interview: Jul 2012, Port Louis, Mauritius.

[3] Ittoo M, Esquel Ltd. Operation Manager, Interview: April 2011: Royal Road, Mare Gravier, BeauBassin, Mauritius.

[4] Kildduff P, Chi T (2006) Longitudinal Patterns of Comparative Advantage in the Textile Complex-Part 1: An Aggregate Perspective. Journal of Fashion Marketing and Management, 8: 230-244.

[5] Lim Fat E (2010) Vision to Miracle. Mauritius: T-Printers Co. Ltd.

[6] Mohit P, Former Permanent Secretary, Mauritius Ministry of Industry \& Commerce 1968-1991. Interview: Feb 2011, Univ of Mauritius, Reduit.

[7] Peerally J, Cantwell J (2011) The Impact of Trade Policy Regimes on Firms' Learning for Innovation from Suppliers. International journal of innovation management, V 15, n 1, Feb: 29-68.

[8] Tang K, Executive Director, RT Knits. Interview : May 2011, RT Executive Office, SLDC Industrial estate, La Tour Koenig, Pointe aux Sables, Ile Maurice.

[9] www.gov.mu, Accessed 12 Jul 2012.

[10] Wong D, Director, Mauritius Export Processing Zone Association, Interview: March 2011, 6th Floor, Unicorn House, 5 Royal Street, Port Louis, Mauritius.

[11] World Economic Forum, Global Competiveness Report 2013-2014,http://www3.weforum.org/docs/WEF_GlobalCo mpetitivenessReport_2013-14.pdf. Accessed 09 Sept 2013, 15 .

[12] Yeung Lam Ko L (1998) The Economic Development of Mauritius Since Independence,wwwdocs.fce.unsw.edu.au/ec onomics/Research/.../1998_6.pdf. Accessed 28 September 2012.

[13] Yin P, Ha Yeung D, Kowlessur D, Chung M (1992) L'île Maurice et Sa Zone Franche, T-Printers Co. Ltd.

[14] Zhang Q, Hathcote J (2008) Factors Influencing Apparel Imports From China. Clothing and Textiles Research Journal. Vol. 26, No.1, Jan: 23-40. 
[15] Zafar A. (2011). Mauritius: An Economic Success Story:[htt $\mathrm{p}$ ://siteresources.worldbank.org/AFRICAEXT/Resources/Ma uritius_success.pdf]. Accessed 11 Sep 2013.

[16] http://www.gfmag.com/tools/global-database/economic-data /10292-economic-freedom-by-country-2010-ranking.html\#a xzz27kUi23Cd]. Accessed 28 Sept 2012. 